\title{
ORGANISATIONAL MOTIVATION AND EMPLOYEE PERFORMANCE IN NIGERIAN UNIVERSITY: A CASE OF FEDERAL UNIVERSITY OYE-EKITI (FUOYE), NIGERIA
}

\author{
Olasehinde, Sunday Adeniyi \\ Department of Business Administration, Federal University, Oye-Ekiti \\ Onibon, Modupe Titilayo Grace \\ Department of Business Administration, Federal University, Oye-Ekiti \\ Ogundipe, Christie Folake \\ Department of Business Administration, Ekiti State University, Ado-Ekiti \\ Bankole, Oluwole Adeniyi \\ Department of Business Administration, Ekiti State University, Ado-Ekiti
}

\begin{abstract}
Motivation is the key of a successful organisation to maintain the continuity of the work in a powerful manner and help organizations to survive. The only way to get people to like working hard is to motivate them. This research aims to investigate the effect of organisational motivation on employee performance, using Federal University Oye-Ekiti. Primary case study data and direct observation methods were used in data collection. Wellstructured questionnaires were distributed to 315 members of staff out of 1,470 who were both an academic staff and non-academic staff. A five level Likerts scale measure at different level of agreement to the questions on organisational motivation and how it influences employee performance. The presentation was in tabular form for quantitative data and descriptive analyses. The hypothesis was tested on 0.05 level of significance using multiple regression. The results and findings indicated that the hypothesis testing relationship between motivation indicator and employee performance showed significant relationship with the following indicators; sponsored training, increase salary and open room for staff participation in the decision pertaining their unit/department has influence on their performance.
\end{abstract}

Keywords: Organisational Motivation, Employee Performance

\section{INTRODUCTION}

In today's chaotic business environment, success depends on employees utilizing their talents. Despite the myriad of available theories and practices, there has always been a misconception around motivation because individuals are motivated by different things or needs and in different ways [1]. According to [2], Motivation is the key of a successful organization to maintain the continuity of the work in a powerful manner and help organizations to survive. The only way to get people to like working hard is to motivate them. Today, the interest of many business owners and stakeholder was to understand the rationale that can make their employees work harder. Every individual in an organization is motivated by some different way. When talking in term of employee motivation, it can be simply defined as "Employee motivation is a reflection of the level of energy, commitment, and creativity that a company's workers bring to their jobs". For the success of any organization motivation play an important role. All organization encounters the matter of motivation whether they are in the public or private sector [3]. Attractive Salaries or pays also a valuable tool and play an important role to increase employee's performance and also increase the productivity of an organization [4].

[5] argued that "Motivation" is "A combination of goals towards which human behaviour is directed; the process through which those goals are pursued and achieved and the social factors involved". [6] says, "Motivation is a combination of needs, drives and incentives. Motivation is defined as the process that starts with physiological or psychological deficiency 
or need that activates behaviour or a drive that is aimed at a goal or incentive". Motivation refers to an internally generated drive to achieve a goal or follow a particular course of action. Highly motivated employees focus their efforts on achieving specific goals. It's the manager's job, therefore, to motivate employees to get them to try to do the best job they can. The main objective of this study is to investigate the effect of organisational motivation on employee performance of Federal University Oye-Ekiti.

\section{Problem Statement}

This study was carried out among the employees of Federal University Oye-Ekiti, which is faced with the problem of development and sustaining staff engagement. It is no longer news that many staff are leaving the institution to other ones due to lack of motivation. And management on the other hand, were trying their best to motivate FUOYE staff but attitude of some staff are not helping to achieve the pace of institutional goals. The incessant union's agitation for staff welfare which led to lingering internal conflict among unions and management call for this research work to seek solution to the problem. The SERVICOM Unit in the University stand as a bridge between staff and management to facilitate effective performance and provision of needed motivation strategy to achieve the University mission statement of innovation and character for national transformation. In order to ensure that people employed in the organisation perform optimally towards the realization of organisational goals, they need to be motivated to work. Motivating people to work entails meeting their needs. There is a great controversy over the issue of motivating people. Some people are of the view that such extrinsic factors like money, praise, and quality of supervision and company's policy can motivate people to work, while others are of the view that such extrinsic factors, like advancement, quality of the job done by person, recognition and growth only may not motivate workers to productivity. But high statistical relationship between the two were not instituted. Notwithstanding, this research work will investigate the effect of organisational motivation and employee performance of Nigerian University. The objective is to render useful information to managers on how employees' performance can be increased by intrinsically or extrinsically motivating them. Several studies had been conducted on motivation and employee performance by scholars in Nigeria and abroad ([7], [8], [9], [10], [11]). From all these studies and to the best of my knowledge, there has not been a unanimous finding between organisational motivation and employee performance. Through motivation to achieve high employee and organisation productivity and prevent low employee morale and low overall institutional performance, the paper aimed at identifying various strategies and motivational techniques that exist in the institution (FUOYE), determination of the best motivational techniques that bring the best out of employees and to determine ways of improving overall institutional productivity through appropriate motivational approach. The rest of the paper is organized as follows: the nexus between motivation and performance is explained in section II. Section III contained the study methodology, data presentation and interpretation is explained in section IV while conclusion, recommendation and suggestion for further studies are presented in section V and VI.

\section{LITERATURE REVIEW}

There were quite a number of academic submissions and professional writings conducted on this subject matter. The earliest economist such as [12] sees man as a rational animal motivated by the desire to maximise his economic gain and this has subsequently led management to believe that workers can be instantly motivated to increase production by means of mere promise of more money. However, the psychological theory of motivation gives one an insight into factors which influence human behaviour on the attitudinal disposition of the individuals as [13] divided motivational theories into two categories termed content and process. In content theory, it is assumed that every individual possesses the same set of needs, which is, having similar needs while the process theory stresses differences in people's needs and focus on the cognitive processes that create these differences.

Motivation is said to be multidimensional [14]. First, the arousal of need which creates a state of disequilibrium (i.e. tension) within the individuals, these individuals will then search for and choose strategies to satisfy these needs. Thirdly, the individual will engage in goal directed behaviour or performance to carry the selected strategy - creating a basic model of motivation that incorporates the concepts of needs, drives, goals and rewards. In other words, you have certain needs or wants (these terms will be used interchangeably), and this causes you to do certain things (behavior), which satisfy those needs (satisfaction), and this can then change which needs/wants are primary (either intensifying certain ones, or allowing you to move on to other ones). [15] asserted "given some values of ability greater than zero, level of performance is constantly increasing function of amount of motivation. That is to say that the more motivated the worker to perform effectively, the more effective is his performance."

Generally speaking, employee performance depends on a large number of factors, such as motivation, appraisals, job satisfaction, training and development and so on, but this paper focuses only on employee motivation, as it has been shown to influence to a significant degree the organizational performance. As [16] suggested, a motivated employee has his/her goals aligned with those of the organization and 
directs his/her efforts in that direction. In addition, these organizations are more successful, as their employees continuously look for ways to improve their work. Getting the employees to reach their full potential at work under stressful conditions is a tough challenge, but this can be achieved by motivating them. According to the Integrated Model of Work Motivation, an individual's values and personality contribute to the choice of goal, which is influenced by incentives and self-efficacy. This is examined using Vroom's expectancy theory, which explains how rewards initiate behaviour by concentrating on the state of one's internal perception, which affects motivation. The theory assumes that an individual will be highly motivated when he or she believes that their behaviour will cause a desired reward or outcome. Likewise, the individual will not be motivated to work if he or she does not believe that his or her behaviour will amount to the desired outcomes or rewards. Also, the individual will not be motivated to work if he or she does not want the rewards or outcomes [17].

[18] conducted an experiment to show the disruption effects of high levels various lengths of food deprivations. The solution of each of the problems requires the animal to use materials provided (e.g string, rope, or stick) to obtain food. Brich found the intermediate length of food deprivation, which we can assume to represent the intermediate level of motivation to get food, to be the most conducive to problem solving efficiency. Relatively short and relatively long periods of food deprivation resulted in less efficient behaviour. This experiment demonstrates the different bases for the ineffective performance of animals under condition of very low and very .high motivation. The nature of the relationship between the amount of motivation and level of performance may vary somewhat with the task being handled. Most investigators have suggested that the inverted U- function must closely approximate the actual state of affairs. According to [19] as a motive increases in intensity it first leads to an increase in the efficiency of instrumental activity and then to a decrease. Too little motivation leads to sluggishness and inertia and too much leads to disruption and defense against anxiety. The question which we may want to ask is, why should performance decrease with increase in motivation? The answer to this question may be more than one, but one type of motivation all the time may produce negative results. For example, the federal government rewarding system (motivation) with respect to the Nigeria national term has proved the theory right.

One of the widely accepted theories of motivation is the hierarchy of needs propounded by a psychologist, Abraham Maslow. He ranked human needs in ascending order from the lowest to the highest needs. In his theory, we can deduce that human needs are continuous and that the satisfaction of one need leads to another higher need in the hierarchical level. These needs are in order of importance such that lower needs must be satisfied before the needs at immediate higher level of hierarchy. [20] theory of motivation, Maslow in his book outlined his theory of motivation. In his need hierarchy Maslow states that there are at least five set of goals which are called the basic needs.

Physiological need: It is the basic form of need which includes food, shelter and clothing. E.g., getting a job for survival in the context of an organisation.

Safety need: With physiological needs being met, a need for stability and safety comes into the picture. E.g., job security.

Social need: It is a sense of belongingness to the society. In the context of an organization, this simply means having good work relations with colleagues and superiors.

Esteem needs: This includes admiration, status and self-respect. E.g., employees in an organization need recognition for their efforts in achieving the predetermined goals.

Self-Actualization: This is a need for personal development and self-fulfillment. E.g., growth in a profession or moving up the ladder in an organization. Maslow's theory acts as a good base for managers to motivate employees.

In 1943, Maslow argued that human beings have an internal needs compelling them in the direction of self-fulfillment and personal superiority. $\mathrm{He}$ then came up with a opinion that there are five unique position of needs and once we to satisfy a need at one position of the hierarchy it will have an influence on our attitude. At such stage our attitude starts to decrease, we now put more powerful influence for the need at the next stage up the hierarchy. [21] introduced a well-known motivation theory, which is the two-Factor Theory, he described in his theory between motivators and hygiene factors. He emphasized that the factors can either be motivators or hygiene factors, but can never be both at the same time. Intrinsic motivational factors are challenging work, recognition and responsibilities. Hygiene motivators are extrinsic motivational factors. Motivating factors can, when present, leads to satisfaction and Hygiene factors can, when not present leads to dissatisfaction, but the two factors can never be treated as opposites from each other [22] Hygiene factors include such things like salary, working condition, job security status, company policy, quality of technical supervision. The existence of these categories of needs in the work place does not motivate in the sense of yielding satisfaction, their lack of existence would however result in dissatisfaction. According to Herzberg, the motivators do not prevent dissatisfaction; rather they help to motivate workers to performance. These factors include achievement, recognition, challenging 
work, advancement and growth in the job. Their presence helps to motivate workers to performance.

\section{Employee Performance}

An effective performance management action is an important tool for employee motivation for optimal performance. However, it is not an enough condition for effective performance management. The most important issue with any performance management system is how critically it is taken and how devotedly it is used by managers and employees. [23] Performance management is all about perfection, synchronizing, upgrading to create value for and from customer with the result of economic value creation to stockholders and owners. The expansion of performance management is clearly very large, which is why performance management must be viewed within an enterprise as a tool to improve on employee motivation for high performance. [24] Efficient management of performance requires a strong apprehension of the performance domain. That is, apprehending the obligation and projects that are part of the job description within a company or organization. Once you have a full skills of what the job requires, you have the basis for assessing and enhancing performance. This is the foundation for assessing and improving performance within a company. When this is lacking, the outcome is a missing link in evaluating employee performance and the possibility of improving on the employee performance within the organization. Moreover, there is also the missing link in assessing employee's performance in relationship to other colleagues in the same job description [25].

Performance in organization can be divided into organizational performance and job performance [26]. According to Otley, the performance of organization is subjected to the performance of employee's job performance and other components such as environment of the organization. The difference between organizational and job performance is apparent; an organization that is performing well is the one that is successfully reaching its objectives, in other words: one that is in effect carrying out an appropriate plan and job performance is the single outcome of an employee's work. Furthermore, high job performance is the ability of the employee himself. The employee must be able to give a better result and also have a high productivity [27].

A good employee performance is necessary for the organization, since an organisation's success is dependent upon the employee's creativity, innovation and commitment [28]. Good job performance and productivity growth are also important in stabilizing our economy; by means of improved living conditions, high wages, increase in the availability of goods for consumption, etc. [29] also argue that therefore research of individual employee performance is important to society in general. Employee production and employee job performance seems to be related; e.g, in the U.S. performance in some cases are measured as the number and value of goods produced. However, in general, productivity is associated with production-oriented terms (profit and turnover) and performance is linked to efficiency or perception oriented terms (e.g. supervisory ratings and goal accomplishments [29].

\section{High Performance Work Systems}

In more recent times, researchers have put all these ideas about making work more motivating together and theorised what a 'high performance work system' would look like. It is argued that high performance work systems would involve recruitment practices which aim to attract and select highly committed and flexible people, internal labour markets which reward commitment and training with promotion and job security, and methods of direct communication and team-working [30]. According to [31] there are seven practices used by successful organisations. The first practice is employment security. Employment security is a crucial practice that underpins the other six high-commitment HR practices. This is mainly because it would appear to be unrealistic to ask employees to be committed and hardworking if there is no expectation of security on employees' part. The second practice is selective recruitment. Recruitment is argued to be an important way of realising 'human capital advantage,' and the selective element is seen by firms that hire exceptional individuals so as to "capture a stock of exceptional human talent" [32], which would be a source of competitive advantage. The third practice is training. According to [33], extensive training, learning, and development are the most crucial elements of high commitment HRM, particularly because it is the way that organisations can make sure that they outstanding employees stay at the forefront of their fields.

The fourth practice is team working. This element has become ubiquitous in the business and management literature for a range of reasons and team working has now been identified by most employers as a very important in building the organisation. The fifth practice identified by [31] is high compensation based on organisational performance. That is, organisations can only expect employees to be committed to the organisation if they provide employees with (1) above average compensation and (2) performance-related reward, which would both demonstrate to employees that those that make superior contributions will be rewarded accordingly. The sixth practice is the reduction of status differentials, such as shared canteens. This is an important practice because it shows that all employees are valuable and thus they deserve to be treated in a similarly manner as more senior staff. The seventh practice highlighted by [31] is information sharing and employee involvement. He argues that this is important because open communication about financial performance, strategy, and operational measures sends employees 


\section{International Journal of Engineering Applied Sciences and Technology, 2020 \\ Vol. 5, Issue 4, ISSN No. 2455-2143, Pages 648-656 \\ Published Online August 2020 in IJEAST (http://www.ijeast.com)}

the message that they are trusted. Additionally, the information on which employees base their suggestions and on which they work has to be good. Overall, it can be argued that this theory of highperformance work systems incorporates both motivating and de-motivating factors and provides managers with a template as to how to deal with this together. While it does not specifically talk about how the job itself is to be designed, it does seem that workers in such a system would be given increased challenge and responsibility, as well as opportunities for advancing in the organisation, personal growth, and organisational recognition, all things that Herzberg argued are needed to motivate workers and make them perform at a high level.

\section{Lindner's System of Employee}

According to [34] it is important to keep the employees motivated to aid a company's survival. Due to the fact that no two individuals are equally alike and the needs of employees changes constantly over time, motivating employees is known to be one of the most complex task for managers. The target group was asked to rank the factors in a descending order: from the most motivating to the least motivating. Thus, the respondents ranked the motivational factors in the following order; interesting work, good wages, appreciation of work well done, job security, good working conditions, personal loyalty to employees, tactful discipline, sympathetic help with personal problems, promotion and growth, feeling of been in on things. All these factors are explained below.

i. Interesting Work: Employees could be motivated through interesting work. Work can be interesting when jobs are well structured and specific goals are properly stipulated [35].

ii. Good Wages: In a bid to enhance motivation and performance, organisations link incentives to better performance. Financial incentives have always been a vital motivator. However, money is not the only motivator, as it cannot always determine employees' productivity. Hence, financial incentives could be viewed as a short-term satisfier [36].

iii. Appreciation of work well done: This can be achieved by giving employees public recognition, feedback, promotion, and reward. Employees could view the need for appreciation for a job well done more important than the need for financial incentives [37].

iv. Job security: Companies usually lay off employees in a bid to restructure the organisation, save cost and be competitive. Employees can be more motivated if given a certain level of job security [38]. v. Good working conditions: Employees could be motivated by good working conditions such as flexible working hours, and so forth flexible and reasonable [35].

vi. Personal loyalty to employees: The instability of employment depicts a change in employers' views towards the employment relationship. Enhancing employee motivation can be done through improving the employee-employer relationship. Sharing information and celebrating successes, with employees to foster a sense of ownership, can show loyalty to employees [36].

vii. Tactful discipline: It is important that every organisation possess a structure of justice where rules, regulations and discipline can be exercised. However in applying discipline, managers should be just an affair and thus create [39].

viii. Sympathetic help with personal problems: Employees can be motivated when employers show interest in their welfare. It is essential for managers to ascertain employees; needs in order to determine what motivates them. Managers get their work done through employees. If managers do not know what employees need, they may also not know what motivates them [36].

ix. Promotions and growth in the company: Training and development in an organisation helps to foster growth in a company, which is beneficial to employees, and the company at large. Both the employees and the company benefit, not just in the present, but also in the future [35].

$\mathrm{x}$. Feeling of being in on things: Employees develop a sense of belonging when involved in decision making and empowerment, It Empowering employees is so vital because a company needs its employees' skill, experience, knowledge, and commitment to the organisation. Experience and skills and their commitment to the company [40].

From the research carried out by [34], he concluded that the findings imply that employees are motivated by different factors according to the context in which they work. Also a high number of employees ranked interesting work as the most important motivational factor, while feeling of being in o things was ranked the lowest motivational factor. These motivational factors will form the basis for data collected in this research. Just like any long existing institution Federal University Oye-Ekiti is faced with the problem of developing and sustaining staff engagement through motivation to achieve high employee and institution productivity and prevent low employee morale and low overall institutional performance, the paper aimed at identifying various strategies and motivational techniques that exist in 
the organization, determination of the best motivational techniques that bring the best out of employees and to determine ways of improving overall institutional performance through appropriate motivational approach. This paper adopted a mixed method approach in collection of the data from eligible respondents.

\section{METHODOLOGY}

The study population of this research was the staff of Federal University Oye-Ekiti, Nigeria. Federal University, Oye-Ekiti, is one of the nine Federal Universities established by the Federal Government of Nigeria, pursuant to an executive order made by the President of the Federal Republic of Nigeria, His Excellency, Dr. Goodluck Ebele Jonathan, GCFR, in January, 2010. With this, the institution went on record as the first new University to have taken off on its permanent campus among the nine (9) Universities established in 2010. A primary case study data and direct observation methods were used in data collection. Well-structured questionnaires were distributed to 315 members of staff out of 1,470 who were both an academic staff and nonacademic staff. A five point Likerts scale measure at different level of agreement to the questions on organizational motivation and how it influences employee performance. Descriptive and inferential statistic were employed where descriptive through frequency table was used to analyse the demographic information while inferential statistic through multiple regression was used to analyse the study objective.

\section{Sample size}

Sloven Formula was being used to determine the sample size. Denoting by $\mathrm{n}$ the sample size is given by $\mathrm{n}=\mathrm{N} /\left(1+\left(\mathrm{N}^{*} \mathrm{e}^{\wedge} 2\right)\right) \frac{N}{1+N(e 2)}$

Where $\mathrm{n}=$ sample size

$\mathrm{N}=$ total target population

$\mathrm{e}=$ level of significance/marginal error which is not more than $5 \%$

$\mathbf{n}=\frac{1470}{1+1470(0.0025)}=\frac{1470}{4.675}=315$ participants

\section{DATA PRESENTATION, ANALYSIS AND INTERPRETATION}

This section focuses on the presentation, analysis and interpretation of the sample respondents from staff of Federal University Oye-Ekiti on Organisational Motivation and Employee Performance in Nigerian University: A Case of Federal University Oye-Ekiti (Fuoye), Nigeria. The analysis shows the percentage distribution of the background characteristics of respondents and key motivational strategies as well as test of relationship between motivation and employee performance.

Table 1:_Background_Characteristics_of Sample FUOYE Staff

\begin{tabular}{lcc}
\hline SEX & FREQUENCY & PERCENTAGES \\
\hline Male & 155 & 49.3 \\
Female & 160 & 50.7 \\
\hline LEVEL OF EDUCATION & & 14.5 \\
PhD. & 46 & 32.1 \\
M.Phhil/M.Sc./M.Eng./M.Tech./M.A./MBA & 101 & 21.3 \\
B. Sc./B.Edu/B.A/B.Tech./B.Eng & 67 & 21.3 \\
\hline HND & 67 & 10.8 \\
ND/NCE & 34 & 29.2 \\
CATEGORY OF STAFF & & 70.8 \\
\hline Academic Staff & 92 & 35.9 \\
Non-Academic Staff & 223 & 64.1 \\
\hline WORKING EXPERIENCE & & 100 \\
\hline 0-5 years & 113 & 202 \\
\hline 5-10 years & 315 & \\
\hline TOTAL & & \\
\hline
\end{tabular}

The background information of the sampled respondents in this study disclosed that female counterpart is more than male counterpart as male staff took $155(49.3 \%)$ while the female staff 160
(50.7\%). About (46) $14.6 \%$ of the sampled staff had $\mathrm{PhD}$ as their highest level of education, (101) $32.1 \%$ had MSc while those with BSc./B.edu/B.A/B.Tech./B.Eng had (67) $21.3 \%$, HND (67) $21.3 \%$ and ND/NCE (34) $10.8 \%$ thus 


\section{International Journal of Engineering Applied Sciences and Technology, 2020 Vol. 5, Issue 4, ISSN No. 2455-2143, Pages 648-656 \\ Published Online August 2020 in IJEAST (http://www.ijeast.com)}

implied that staff with M.sc covers the larger part of the academic qualifications. Presently as at the period of this study, non-academic staff were more than the academic staff thus, academic staff had $29.2 \%$ among the sample respondent while $70.8 \%$ of the sampled staff were non-academic staff. More than $60 \%$ had been in the institution for more than 5years while those with less than 5years in the institution were $35.9 \%$. This implies that the sample population were those who had been in the university environment for at least 5years who cuts across the level of academic qualifications.

\section{Discussion of Result}

Organisational motivation does not have significant effect employee performance in Nigerian Universities.

Table 2: Regression Results of Organisational Motivation on Employee Performance

\begin{tabular}{|c|c|c|c|c|c|c|c|}
\hline \multirow{2}{*}{ Model } & $\mathbf{R}$ & $\mathbf{R}^{\mathbf{2}}$ & Adj R & $\mathbf{B}$ & Std Error & T value & $\begin{array}{c}\text { P } \\
\text { Value }\end{array}$ \\
\cline { 2 - 8 } & 0.639 & 0.408 & 0.402 & & & & .000 \\
\hline Financial Benefits & & & & .696 & .068 & 5.969 & .000 \\
\hline $\begin{array}{c}\text { Work Environment } \\
\text { Training and } \\
\text { Development }\end{array}$ & & & & .331 & .051 & 4.561 & .000 \\
\hline Employee Involvement & & & & .413 & .053 & 5.909 & .000 \\
\hline Constant & & & .400 & .063 & 4.757 & .000 \\
\hline F - Cal - 67.694* & & & 0.795 & .155 & 5.132 & .000 \\
\hline
\end{tabular}

Source: Field Survey, (2019)

Four variables (financial benefits, work environment, training and developmental opportunities and employee involvement) were used to proxy organisational motivation From Table 2, the R (Regression Coefficient) gives a positive value of 0.639 ; this indicates that organisational motivation have a strong and positive effect on employee performance. The $\mathrm{R}^{2}$ is a portion of the total variation in the dependent variable that is explained by the variation in the independent variables. From the results obtained, $\mathrm{R}^{2}$ is equal to 0.408 , this implies that organisational motivation about $40.8 \%$ variance in employee performance in Nigerian Universities, this is further proven by the adjusted $\mathrm{R}^{2}$ that shows the goodness of fit of the model which gives a value of 0.402 , implying that when all errors are corrected and adjustments are made the model can only account for $40.2 \%$ of organisational motivation in the surveyed institution. However, four variables were used to proxy organisational motivation which the variables are listed as: financial benefits, work environment, training and developmental opportunities and employee involvement. The variables are subjected to multiple regression analysis as shown in Table 2.

From the Table 2 , the unstandardized $\beta$ co-efficient of financial benefits gives a positive value of 0.696 with $\mathrm{t}=5.969$ and $(\mathrm{P}=0.000<0.05)$. This result showed that financial benefits have a higher significant effect on employee performance, therefore, it was found significant. This means that respondents' reason for employee performance is strongly and positively influenced by financial benefits like regular salary and fringe benefits and allowances as depicted in Table 2. This is in line with the findings of [41] who examined place of reward system on employee's performance in Lagos State. The study revealed that there is a significant relationship between salary package, employee job allowance and employee's performance

The unstandardized $\beta$ co-efficient of work environment gives a positive value of 0.331 with $\mathrm{t}=$ 4.561 and $(\mathrm{P}=0.000<0.05)$. This result showed that work environment has a significant effect on employee performance therefore, it was found significant. This means that respondents' reason for employee performance is significantly and positively influenced by the environment of the organisation such as furniture and office layout, modern equipment and physical structures which aids free flow of operations as shown in Table 2. This is in accordance to the findings of [42] who analyzed the influence of workplace environment on workers welfare and productivity in government parastatals of Ondo State, Nigeria. The study found that workplace features and good communication network at workplace have effect on worker's welfare, health, morale, efficiency, and productivity.

From the Table 2 , the unstandardized $\beta$ co-efficient of training and developmental opportunities gives a positive value of 0.413 with $\mathrm{t}=5.909$ and $(\mathrm{P}=0.000<$ $0.05)$. This result showed that training and developmental opportunities has a great significant effect on employee performance, therefore, it was found significant. This means that respondents' reason for employee performance is strongly and positively influenced by periodic and sponsored training, conferences, workshops and seminars as shown in Table 4.2. This is in line with the findings of [43] who investigated the effectiveness of training and development on employee $\mathrm{p}$ and organisational competitiveness in the Nigerian Banking Industry. 


\section{International Journal of Engineering Applied Sciences and Technology, 2020 \\ Vol. 5, Issue 4, ISSN No. 2455-2143, Pages 648-656 \\ Published Online August 2020 in IJEAST (http://www.ijeast.com)}

The study found that strong relationship exists between training and development, employee performance and organisational competitiveness.

From the Table 2, the unstandardized $\beta$ co-efficient of employee involvement in decision making gives a positive value of 0.400 with $\mathrm{t}=4.757$ and $(\mathrm{P}=0.000<$ $0.05)$. This result showed that employee involvement in decision making has a great significant effect on employee performance, therefore, it was found significant. This means that respondents' reason for employee performance is strongly and positively influenced by employee participation in decision that has to do with their daily work and organisational financial status as shown in Table 4.2. This is in line with the findings of [44] who determined the effect of employee involvement on job performance in the medical research industry in Kenya. The study found that employee involvement is an important means to increase employee's performance.

The F-test is used to test the overall significance of a model by comparing the $\mathrm{F}$ calculated with the $\mathrm{F}$ tabulated, the comparison is done on Table 2. The table shows that the calculated value of $F$ distribution gives a value greater than the F tabulated. Hence, we accept alternate hypothesis and reject null hypothesis. This implies that organisational motivation will significantly affect employee performance in Nigerian Universities.

\section{CONCLUSIONS}

This study focused on organisational motivation and employee performance in Nigerian University with respect to Federal University, Oye Ekiti. Conclusively, from the hypothesis tested, motivation indicator significantly affect employee performance with the other indicators like sponsored training, increase salary and open room for staff participation in the decision pertaining their unit/department has influence on their performance. Recognition and empowerment play an essential part in enhancing employee motivation towards institutional tasks. By appreciating the employees for their work and giving them participation in decision making, creates work satisfaction with their job and organisational environment. Hence, their enthusiasm and motivation towards accomplishment of different tasks increases. In view of this, this study concluded that organisation motivation is positively related to employee performance in Nigerian University.

\section{RECOMMENDATIONS}

Based on the findings of this study, the following recommendations are made:

Institution leadership and management should provide adequate fringe benefits to the employee and such benefits should be geared towards meeting the needs of the employee The University management should encourage the staff training and development.
Learning and development opportunities are an important factor in motivating employees for superior performance in an organisation. The rewards employees enjoy in the institution should be benchmarked and at par favorably with the reward which employees in other similar institutions enjoy. This is important because employees perception of what obtained in other institutions can affect their level of motivation. We have also tried to show that low motivation has the same negative effect on performances as much as high motivation. Motivation should not be a once and for all affairs, rather there must be reinforcing elements to keep it sustained.

\section{REFERENCES}

Ghebregiorgis, F., \& Karsten, L. (2007). Human resources management practises in Eritrea: Challenges and prospect. Employees Relations, 28(2), (pp. 144-163).

Omollo, A. P. (2015). Effect of motivation on employee performance of commercial banks in Kenya: A case study of Kenya Commercial Bank in Migori County. International Journal of Human Resource Studies, 5(2), (pp. 87-103).

Chintalloo, S., \& Jyoti, M. (2013). Effect of Motivation on Employees' Work Performance at Ireland Blyth Limited. Proceedings of 8th Annual London Business Research Conference Imperial College. http://wbiworldconpro.com. (Pp.116).

Muogbo, U. (2013). The impact of employee motivation on organisational performance: A study of some selected firms In Anambra State Nigeria. The International Journal of Engineering and Science, 2(7), (pp. 70-80).

Huczynski, A. A., \& Buchanan, D. A., (2007). Organizational behaviour. ( $6^{\text {th }}$ ed.): Instructor's Manual.

http://ntu.ac.uk/Staff\%20Profiles/Document \%20uploads/158404.pdf . ( Pp. 1-20).

Luthans F (1992). Organisational behaviour, Mc Graw Hill. ( $2^{\text {nd }}$ ed.): Irwin. Boston.

Obiekwe N. (2016). Employee motivation and performance. Thesis Centria University of applied Sciences, Business Management.

Kristína, T. (2016). Motivation, performance and efficiency, Univerzitná 8215/1 Žilina, 010 26, Slovakia.

Bott, H. D., \& Asaju, K. T. (2015). Motivation and job performance of university workers: A case Study of Plateau State University Bokkos.

Obajemu, A.S., Dekpen, N. A., \& Ojo, J. A. (2012). Staff motivation in the University of Lagos Libraries, Nigeria". Library Philosophy and Practice (e-journal). (pp. 753).

Stajkovic, A. D., \& Luthans, F. (2001). Differential effects of incentive motivators on work performance. 


\section{International Journal of Engineering Applied Sciences and Technology, 2020 Vol. 5, Issue 4, ISSN No. 2455-2143, Pages 648-656 \\ Published Online August 2020 in IJEAST (http://www.ijeast.com)}

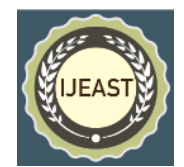
580-590).

Academy of Management Journal, 4(3), (pp.

Adams, J. S. (1995). Inequity in Social Exchange. In L. Berkowitz (ed.), Advance in experimental social psychology. New York: Academic Press

Robbins, S. P., \& Coulter, M. (1996). Management ( $5^{\text {th }}$ ed.). Englewood Cliffs, NJ: Prentice-Hall, Inc.

Obadofin, H.G. (2001). Staff motivation in Local Government Establishment: A case study of Mopamuro Local Government Area of Kogi State. Dissertation submitted to Ondo State Polytechnic, Owo.

Vroom, V. H. (1964). Work and Motivation. New York: Wiley.

Kalimullah, A. R., Yaghoubi, N. M., \& Moloudi J. (2010). Survey of relationship between organizational justice and empowerment (A Case Study). European Journal of Economics, Finance and Administrative Sciences, 24, (pp. 165-171).

Spector, P. E. (2000). Industrial and organizational psychology: research and practice. ( $2^{\text {nd }}$ ed.): Chichester: John Wiley \& sons, Inc.

Birch, H. G. (1945). The relation of previous experience to insightful problem-solving. Journal of Comparative Psychology, 38, 367-383.

McClelland, D.C. (1951). Personality. NY: William Sloane Associates.

Maslow, A. H. (1943). A theory of human motivation. Psychological Review, 50(4), (pp. 37096).

Herzberg, F. (1959). The motivation to work. New York: John Wiley \& Sons.

Saiyadain, M. (2009). Human resources management. McGraw-Hill, Inc.

Pulakos, E. D. (2009). Performance management: A new approach for driving business result. WileyBlackwell, Inc.

Cokins, G. (2009). Performance management: Integrating strategy execution, methodologies, risk and analytics. John Wiley and Sons, Inc.

Robert, C. L. (2003). Performance management: Concept, skills and exercises. M.E. Sharpe, Inc.

Otley, D. (1999). Performance management: A framework for management control systems research. Management Accounting Research, 10, (pp. 363-382).

Hunter J. E. (1986). Cognitive ability, cognitive aptitudes, job knowledge and job performance. Journal of Vocational Behaviour.

Ramlall, S. J. (2008). Enhancing employee performance through positive organizational behaviour. Journal of Applied Social Psychology, 38(6), (pp. 1580-1600).

Griffin, R.W. (1981). Perceived task characteristics and employee productivity and satisfaction. Paper presented at the annual meeting of the Academy of Management, San Diego.

Wood, S. J., \& De Menezes, L. (1998). High commitment management in the UK: Evidence from the Workplace Industrial Relations Survey and Employers' Manpower and Skills
Practices Survey. Human Relations 51(4), (pp. 485515).

Pfeffer, J. (1998). Six dangerous myths about pay. Harvard Business Review, 76, (pp.108-120).

Boxall, P. F. (1996). The strategic HRM debate and the resource-based view of the firm. Human Resource Management Journal, 6(3).

Marchington, M., \& Wilkinson, A. (2005). Human Resource Management at Work: People Management and Development, The Chartered Institute of Personnel and Development, London.

Lindner, J. R. (1998). Understanding employee motivation. Journal of extension.

Sorita, D., Mischkind, L. A., \& Meltzer, M. I. (2005). The enthusiastic employee: how companies profit by giving workers what they want. Upper

Saddle River, New Jersey: Wharton School Publishing.

Drafke, M. W., \& Kossen, S. (2002). The human side of organisations. 8th ed. Upper Saddle River, New Jersey: Prentice Hall.

Thorpe .R. and Homan G. (2000) Strategic Reward Systems, Person education limited [internet] https://books.google.co.uk/books?id=Nc2Ri q5U9okC\&printsec $=$ frontcover\&source $=$ gbs ge summary_r\&cad $=0 \# \mathrm{v}=$ onepage $\& \mathrm{q} \& \mathrm{f}=$ false.

Sharma, S. (2006). A right way to motivate an employee, is to win his heart!!! [Online] Available from: http://www.bpoindia.org/research/winheart.shtml.

Dreher, G. F., \& Dougherty, T. W. (2002). Human resource strategy: A behavioural perspective for the general manager. Irwin, San Francisco: McGraw-Hill.

Johnson, R., \& Redmond, D. (1998). The art of empowerment: the profit and pain of employee involvement. Washington DC: Financial Times, Pitman Publishing.

Bello, O. W., \& Adebajo, A. A. (2014). Reward system and employees performance in Lagos state: A study of selected Public Secondary

Schools. Arabian Journal of Business and Management Review, 3(8), (pp. 14-28).

Ajala, E. M. (2012). The influence of workplace environment on workers' welfare, performance and productivity in University of Ibadan. An online journal of the African Educational Research Network, 12(1), (pp.141-149).

Falola, H. O., Osibanjo, A. O., \& Ojo, S. I. (2014). Effectiveness of training and development on employees performance and organisation competitiveness in the Nigerian Banking Industry. Economic Sciences, 7(1), (pp. 161-170).

Kasaya, M. A., \& Munjuri, M. G. (2018). Effect of employee involvement on job performance in the medical research industry in Kenya. International Journal of Economics, Commerce and Management, 6(5), (pp. 826-847). 